\title{
DIFERENCINIO MOKYMO POVEIKIS PRIEŠMOKYKLINIO AMŽIAUS VAIKŲ RANKŲ MIKLUMUI
}

\author{
Pavelas Zachovajevas ${ }^{1}$, Viktorija Kaktiené2, Gina Šegždaite் ${ }^{2}$, Jovaidė Jurẻnaite் ${ }^{2}$, \\ Kristina Berškienè ${ }^{2}$ \\ ${ }^{1}$ Kauno kolegijos Medicinos fakultetas, ${ }^{2}$ Lietuvos sveikatos moksly universiteto \\ Slaugos fakulteto Sporto institutas
}

Raktažodžiai: diferencinis mokymas, rankų miklumas, smulkioji motorika, priešmokyklinis ugdymas, rašymo ịgūdžiai, priešmokyklinio amžiaus vaikai.

\section{Santrauka}

İvadas. Mokymasis visą gyvenimą prasideda nuo vienos svarbiausių ugdymosi pakopų - priešmokyklinio vaiko ugdymo. Todèl vaikams reikia smulkiosios motorikos ịgūdžių: jègos ir miklumo, kad galètų suimti rašymo priemonę ir parodyti pakankamus manipuliacinius ịgūdžius, reikalingus rašyti $[2,15]$. Diferencinis mokymas remiasi judesio nekartotinumo principu, tai mokymas, kad pats subjektas mokydamasis kompleksinių motorinių ịgūdžių suranda tik jam vienam optimalius atlikimo modelius [19].

Tiriamieji ir tyrimo metodika. Tyrimas buvo atliekamas Kauno ikimokyklinio ugdymo ịstaigoje. Atrankos kriterijus atitiko 27 priešmokyklinio amžiaus vaikai, iš kurių 15 mergaičių ir 12 berniukų. Tyrimo metu buvo atliktas pradinis ir pakartotinis priešmokyklinio amžiaus vaikų rankų miklumo vertinimas. Visi priešmokyklinio amžiaus vaikai buvo suskirstyti i tiriamają ir ịprasto poveikio grupes. Tiriamają grupę sudare 14 vaikų. Jiems buvo taikomas diferencinis mokymas (du kartus per savaitę) kartu su priešmokykline ugdymo programa (tris kartus per savaitę). Iprasto poveikio grupę sudare 13 vaikų, kuriems buvo taikoma vien priešmokyklinė ugdymo programa penkis kartus per savaitę. Tyrimas truko keturias savaites. Vaikų rankų miklumas buvo vertinamas „Kaištukų lentos testu (angl. Purdue pegboard test)" prieš užsièmimus ir po keturių savaičių užsièmimų.

Rezultatai. Vaikai, kuriems buvo taikyta priešmokyklinio ugdymo programa kartu su diferenciniu mokymu, dominuojančia, nedominuojančia rankomis ir statant bokštelius sudejo reikšmingai $(\mathrm{p}<0,05)$ dau- giau kaištukų nei vaikai, kurie buvo lavinami ịprasta priešmokykline ugdymo programa. Lyginant ịprasto poveikio ir tiriamosios grupių vaikų kaištukų dejjimo abiem rankomis rezultatus, nustateme, kad didesnis pokytis $(\mathrm{p}<0,05)$ nustatytas tiriamojoje grupeje. Tiriamosios grupès vaikai, kuriems greta ịprastos ugdymo programos buvo taikytas diferencinis mokymas, sudèjo daugiau kaištukų porų nei vaikai, kurie atliko tik ịprasto lavininimo užduotis.

Išvada. Priešmokyklinio amžiaus vaikų rankų miklumas buvo geresnis taikant ịprastą ugdymo programą ir diferencinį mokymą nei taikant vien ịprastą priešmokyklinio ugdymo programą.

\section{İvadas}

Miklumas - tai gebejjimas atlikti smulkius, tikslius, kruopščius ir efektyvius rankos judesius be didžiulių pastangų. Kuomet vaikas turi tvirtus ,pamatus“" (stabilumą, abipusę koordinaciją ir pojūčius), tada jis gali atlikti kasdienes veiklas. Viena iš kasdienių veiklų vaikams yra mokyklinė veikla, kuri susijusi su smulkiosios motorikos vystymusi ir apima kopijavimą, piešimą, spalvinimą, kirpimą, rašymą bei kompiuterinius igūdžius. Miklumas pradeda formuotis tada, kai vaikas sugeba sugriebti daiktą ir bando su juo atlikti tikslingus veiksmus. Miklumui formuotis svarbūs keturi gebejjimai: daikto suemimas ir paleidimas, koordinuoti pirštu bei riešo judesiai, nykščio valdymas ir pincetinis griebimas. Juos ịgijęs vaikas gali be didelių pastangų atlikti judesius, reikalingus sudetingai veiklai (rašymui, sagų segimui, raištelių rišimui ir kt.) [3].

Vaikams reikia smulkiosios motorikos igūdžių, tokių kaip jèga ir miklumas, kad suimtų rašymo priemonę ir parodytų pakankamus manipuliacinius įūdžius, reikalingus rašyti. Smulkiosios motorikos koordinacijos ịgūdžiai ir rašymo priemonès suėmimo tipas gali būti naudojami sveikų vaikų rašymo kokybei vertinti [5]. Smulkiosios motorikos ịgūdžiai 
leidžia detaliai suplanuoti ir laisvai manipuliuoti rašymo priemone. Būtent šių igūdžių dèka suformuojama raidès forma ir dydis. Rašymo kokybe susijusi su ịvairiais smulkiosios motorikos kontrolès aspektais: rankų miklumas, griebimas, manipuliavimas delne, raumenų tonusas, praksija ir judesių izoliacija. Smulkiosios motorikos ịgūdžiai yra esminiai, nes tinkamu laiku ir jèga kontroliuoja rankos, plaštakos ir pirštų judesius, reikalingus tiksliai raidei suformuoti. Nepakankami ịgūdžiai šioje srityje veda ị lètą ir neįskaitomą rašyseną [12]. Smulkiosios motorikos koordinacija yra moksliniais tyrimais pagrịstas rašymo komponentas. Teptukai, kreidelès, pieštukai, flomasteriai ar rašikliai yra pirmieji rašymo įrankiai. Jų formų skirtumai rankoje ir kontroliavimas bei manipuliavimas yra svarbūs ịgyti kopijavimo, piešimo ir rašymo ịgūdžius. Smulkiosios motorikos gerinimas svarbus stabilumui ir kontroliuoti dinaminiams pirštu judesiams, reikalingiems rašyti [26]. Taip pat tai yra viena iš sudedamuju fizinio brandumo mokyklai dalių [1]. Vaikai, turintys specifinių mokymosi sutrikimų (skaitymo, rašymo), sunkiau ịsitraukia ị mokyklos ir popamokines veiklas, yra bendravimo su bendraamžiais sunkumų ir emocinių problemų, nemoka spręsti konfliktų, turi menkesnès savigarbos ir menkesnio pasitenkinimo gyvenimu [9].

Rašymas - tai sudètingas kompleksinis ịgūdis, jis formuojamas ne vienerius metus [14]. Tradiciškai rašymas prasideda, kai vaikai rašo raides arba savo vardą [18]. Priešmokyklinis ugdymas yra viena pirmujų ugdymo pakopų, tuomet dažniausiai prasideda mokymasis visą gyvenimą. Jutiminės sistemos, erdvès ir krypties suvokimas, smulkieji raumenys yra būtini sẻkmingai rašyti ir skaityti ar atlikti ịvairius rankų darbelius, todèl nepakankamai išlavintos gali trukdyti vaiko sẻkmei mokykloje. Rašymo mokymas nėra vienas svarbiausių kuriant vaiko pasitikèjimą savimi, tačiau tai sudètinė sèkmès mokykloje dalis. Būtent mokykloje vaikai atlieka nuo 31 proc. iki 60 proc. rašymo ir kitų smulkiosios motorikos užduočių, todèl sunkumai šiose srityje sukuria barjerus tobulinti kitus igūdžius, tokius kaip tarimas paraidžiui ar istorijos kūrimas, jos pasakojimas [3, 13]. 2011 metais Lietuvoje įsigaliojus raidos sutrikimu klasifikacijai, kuri atitinka TLK-10, sutrikimu grupei priskiriami ilgalaikiai mokymosi (skaitymo, rašymo, matematikos mokymosi), taip pat elgesio ir emocijų, kalbos ir kalbejjimo sutrikimai, atsirandantys vaikui siekiant ịsisavinti mokymosi programą. Rašymo sutrikimai yra labiausiai paplitę mokymosi sutrikimai mokyklose tarp pradinių klasių moksleivių [8].

Diferencinis mokymas - judesių kartojimo alternatyva. Šis metodas remiasi judejimo sistemos įvairove, nekartotinumo ir individualumo principais [21]. Pagrindinis diferencinio mokymo metodo tikslas padèti asmeniui rasti individualius, nuo aplinkos - konteksto priklausančius atli- kimo modelius siekant kuo geriau atlikti užduoti [7]. Asmuo, atlikdamas užduoti, pasirenka tik jam vienam priimtinus ir individualius judesio modelius. Socialiai aktyvios asmenybès pamatas vaikui vystantis yra rašymo ịgūdžiu ịgijimas. Tradiciškai nuo pat pradžių vaikai yra mokomi, kaip taisyklingai formuoti raides (tam tikra brūkšnelių seka). Vèliau eina instrukcijos, kaip pasirinkti rašikli, kaip ji laikyti, kokie turètų būti rankos judesiai ar kūno poza. Diferencinio mokymo šalininkai siūlo pakeisti tradicini mokymą, kuris paremtas judesių kartojimu, $\mathfrak{i}$ atsitiktinius trikdžius ir skirtingus judesių mokymosi modelius kaip efektyvaus mokymosi pagrindą [21].

Tyrimo tikslas: ịvertinti diferencinio mokymo poveikị priešmokyklinio amžiaus vaikų rankų miklumui.

\section{Metodika}

Tyrimas buvo vykdomas $2017 \mathrm{~m}$. vasario - balandžio mènesiais. Tyrimo metu buvo atliktas pradinis ir pakartotinis priešmokyklinio amžiaus rankų miklumo vertinimas. Tyrimui atlikti gautas Lietuvos sveikatos mokslų universiteto Bioetikos centro leidimas (protokolo Nr. BEC - ER(B) - 113). Istaigos vadovai bei tirtų vaikų tèveliai buvo supažindinti su tyrimo eiga ir tikslais, gauti raštiški jų sutikimai. Tyrimo imti sudarè 27 šešerių metų amžiaus vaikai, lankantys priešmokyklinę grupę. Visi tiriamieji buvo suskirstyti ị tiriamają ir iprasto poveikio grupes. Tiriamųjų amžiaus vidurkis 78,29 $\pm 3,38$ mèn. (mergaičių amžiaus vidurkis $78,83 \pm 3,24$ mèn., berniukų 77,75 $\pm 3,57$ mèn.). Iprasto poveikio grupę sudarè 13 priešmokyklinio amžiaus vaikų, iš kurių mergaičiu - 5 $(38,46$ proc.) ir berniukų - 8 (61,54 proc.). Tiriamają grupę sudare 11 priešmokyklinio amžiaus vaikų, iš jų mergaičių - 7 $(63,64$ proc.) ir berniukų - 4 (36,36 proc.). Tyrimo nebaigè 3 priešmokyklinio amžiaus vaikai.

Vertinimas bei užsiėmimai ir diferencinio mokymo programa buvo vykdoma šviesioje, šiltoje ir patogioje lopšelio - darželio patalpoje. Tiriamieji atsitiktinès atrankos būdu buvo suskirstyti i dvi grupes: ịprasto poveikio ir tiriamają. Iprasto poveikio grupès vaikų ranku miklumas buvo lavinamas taikant priešmokyklinio ugdymo bendrają programą. Užduotys atliekamos 5 kartus per savaitę, keturias savaites nekeičiant užduoties atlikimo sąlygų, t. y. sédint prie stalo ir ịprastai (tripirštis, keturpirštis suemimas) laikant pieštuką ar rašiklį. Taip pat vaikai rašydavo sąsiuviniuose ịvairius ženklus, skaičius, raides. Ugdomojoje aplinkoje gausu ịvairių priemonių, skatinančių mokytis rašyti raides. Tai ịvairios dèlionès, kaladèlès, lenta, ant kurios rašomos raidès, plakatai. Tiriamosios grupès vaikams, greta ịprasto poveikio, buvo taikytas diferencinis mokymas, siekiant lavinti rankų miklumą. Minètiems vaikams diferencinis mokymas buvo taikomas keturias savaites, 2 kartus per savaitę, likusias 3 
dienas vaikai atlikdavo ịprastas lavinimo užduotis darželio grupèje pagal priešmokyklinio ugdymo bendrają programą. Diferencinio mokymo metodas pagrịstas judèjimo sistemos ivvairove ir nekartotinumo principu, todèl tiriamieji užduotis atliko tokiomis variacijomis: varijuojant subjektu; varijuojant funkciniu kūno lygmeniu; varijuojant atlikimo sąlygomis.

Vaikai turejjo parašyti savo vardą, ịvairias raides, skaičius nuo 0 iki 10, geometrines figūras: tiesią liniją, keturkampi, trikampi, apskritimą. Visas užduotis vaikai atliko pagal išvardintas variacijas, kurias kas du pakartojimus ergoterapeutas keitè.

İtraukimo ị tyrimą kriterijai. Šešerių metų amžiaus vaikai, lankantys priešmokyklinę grupę, kurių dominuojanti ranka - dešinè.

Neįtraukimo ị tyrimą kriterijai. Dominuojanti ranka kairè. Vaikai, turintys raidos sutrikimų bei fizinès veiklos kontraindikacijų.

Visiems tiriamiesiems buvo vertinamas rankų miklumas tyrimo pradžioje ir pabaigoje (po keturių savaičių). Rankų miklumui vertinti buvo naudojamas „Kaištukų lentos“ testas

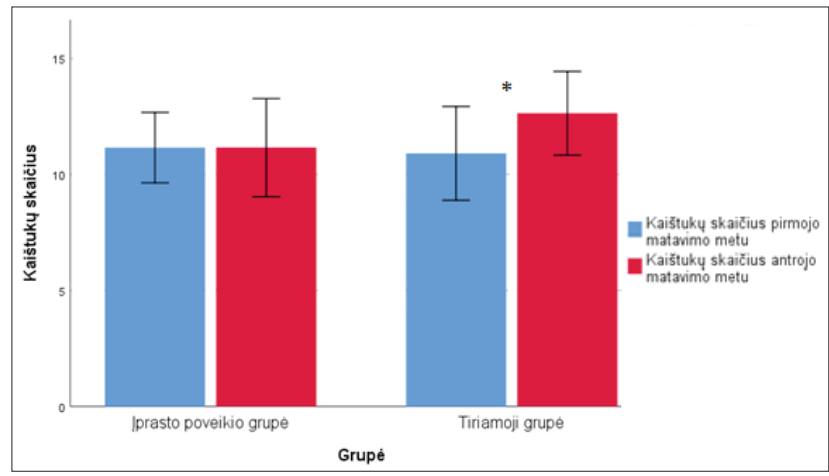

1 pav. Kaištukų dejjimo dominuojančia ranka užduoties rezultatų kaita.

$\left({ }^{*} p<0,05\right.$ lyginant skirstinius $)$

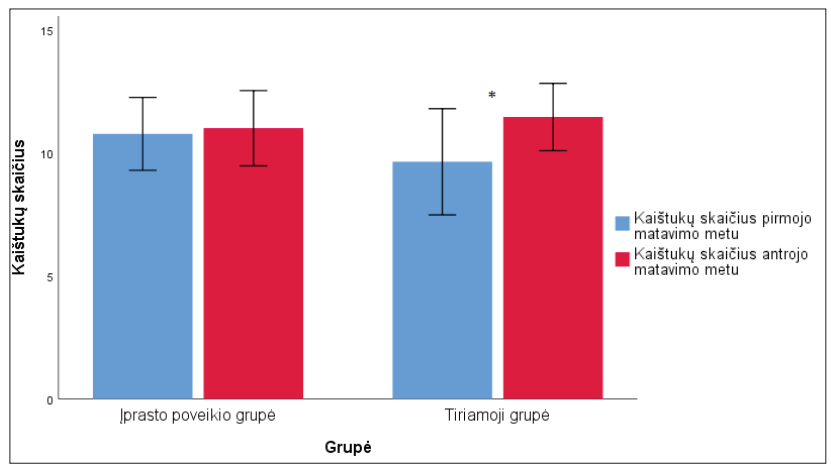

2 pav. Kaištukų dèjimas nedominuojančia ranka užduoties rezultatų kaita.

$\left({ }^{*} p<0,05\right.$ lyginant skirstinius)
(Purdue Pegboard) Tai standartizuotas testas, skirtas 5-89 metų amžiaus žmonèms. Testą sudaro lenta ir 3 rūšių kaištukai: pailgi kaištukai, trumpi vamzdeliai ir apvalūs - plokšti su skylute viduryje. Lentoje yra 50 skylučių, kurios išdèstytos viduryje, dviem eilemis vertikaliai lentos po 25 skylutes. İvertinant vaikų rankų miklumą buvo atliktos keturios užduotys: sudèti kaištukus dominuojančia, nedominuojančia ranka, abiem rankomis bei sudèti bokštelị. Kiekvienai iš užduočiu atlikti buvo skirta 30 sek., bokštelio statymo užduočiai 60 sek. Prieš kiekvieną užduotị vaikams buvo parodoma, kaip ją atlikti, taip pat leidžiama vieną kartą pabandyti.

\section{Rezultatai}

Tarp ịprasto poveikio ir tiriamosios grupių vaikų rankų miklumas prieš tyrimą statistiškai reikšmingai nesiskyrè.

Išanalizavę gautus rezultatus nustatème, kad pirmosios užduoties metu, kurioje reikèjo dominuojančia (dešine) ranka sudèti kaištukus, įprasto poveikio grupès vidutinis kaištuku skaičius pirmojo testavimo metu buvo $11,15 \pm 1,51$, antrojo testavimo metu - $11,15 \pm 2,11$. Tiriamosios grupès vidutinis kaištukų skaičius pirmojo testavimo metu buvo 10,91 $\pm 2,02$, antrojo testavimo metu $-12,64 \pm 1,80$ kaištukai. Vaikai po priešmokyklinès ugdymo programos kartu su diferenciniu

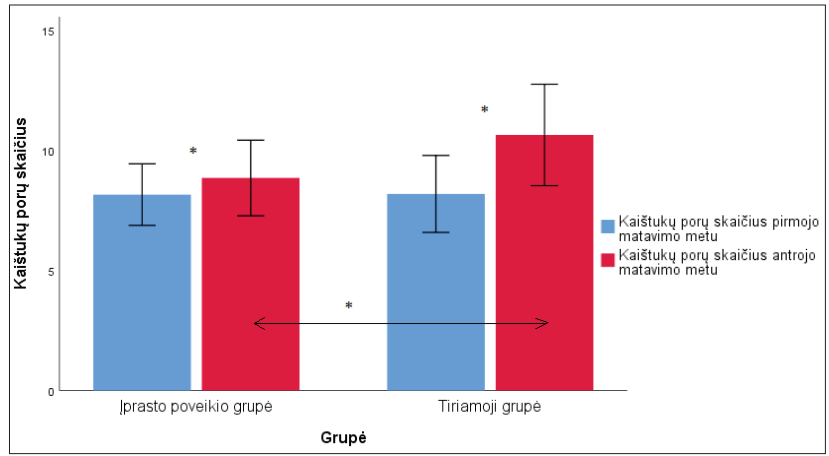

3 pav. Kaištukų dejjimo abiem rankomis užduoties rezultatų kaita. $\left({ }^{*} p<0,05\right.$ lyginant skirstinius)

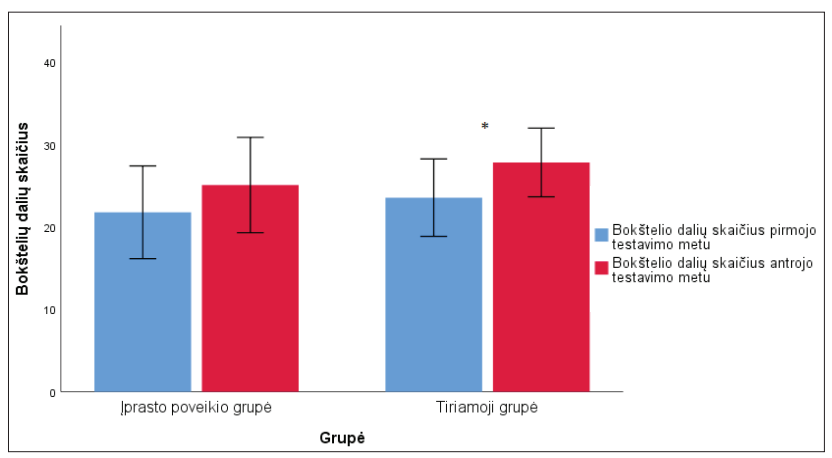

4 pav. Bokštelių dalių skaičiaus rezultatų kaita.

$(* p<0,05$ lyginant skirstinius $)$ 
mokymu sudèjo reikšmingai daugiau kaištukų dominuojančia ranka, nei vaikai po priešmokyklinès ugdymo programos $(\mathrm{p}<0,05) \quad(1$ pav. $)$.

Dedant kaištukus nedominuojančia (kaire) ranka, iprasto poveikio grupės vaikų vidutinis kaištukų skaičius buvo $10,77 \pm 1,48$, antrojo matavimo metu $-11,00$ $\pm 1,52$ kaištukai. Tiriamojoje grupeje vertinant užduoties atlikimą vidutinis kaištukų skaičius pirmojo matavimo metu buvo 9,64 $\pm 2,15$, antrojo matavimo metu - 11,45 $\pm 1,36$. Nustatème, kad tiriamosios grupès vaikai, kuriems greta iprastos ugdymo programos buvo taikytas diferencinis mokymas, nedominuojančia ranka sudèjo daugiau kaištukų nei vaikai, kuriems buvo taikoma vien priešmokyklinio ugdymo programa $(\mathrm{p}<0,05)(2$ pav. $)$.

Iprasto poveikio grupeje vidutinis kaištuku porų skaičius pirmojo testavimo metu $8,15 \pm 1,28$, antrojo testavimo metu $-8,85 \pm 1,57$. Tiriamojoje grupeje vidutinis kaištukuc porų skaičius pirmojo testavimo metu $8,18 \pm 1,60$, antrojo testavimo metu $-10,64 \pm 2,11$. Tiek icprasto poveikio, tiek tiriamojoje grupése palyginus pirmojo ir antrojo testavimo rezultatus, nustatytas statistiškai reikšmingas skirtumas $(\mathrm{p}<$ $0,05)$. Lyginant ịprastos ir tiriamosios grupių vaikų kaištukų dejjimo abiem rankomis rezultatus, nustatème, kad didesnis pokytis $(\mathrm{p}<0,05)$ nustatytas tiriamojoje grupeje. Tiriamosios grupès vaikai, kuriems greta ịprastos ugdymo programos buvo taikytas diferencinis mokymas, sudejo daugiau kaištuku porų nei vaikai, kurie atliko tik įprasto lavininimo užduotis (3 pav.).

Vidutinis bokštelio dalių skaičius ịprasto poveikio grupeje pirmojo matavimo metu buvo $21,77 \pm 5,63$ bokštelių dalių, antrojo matavimo metu $-25,08 \pm 5,78$ bokštelių dalių. Tiriamojoje grupèje vidutinis bokštelių dalių skaičius pirmojo matavimo metu buvo 23,55 $\pm 4,69$ bokštelių dalių, antrojo matavimo metu $-27,82 \pm 4,16$ bokštelių dalių. Lyginant pirmojo ir antrojo matavimo rezultatus, tiriamojoje grupejje po ịprastos priešmokyklinès ugdymo programos ir diferencinio mokymo vidutinis bokštelių dalių skaičius padidèjo $(\mathrm{p}<0,05)(4 \mathrm{pav}$.).

\section{Rezultatų aptarimas}

Rašymo problemos susijusios su prastu rašto ịskaitomumu, mažu rašymo greičiu ir nusiskundimais, tokiais kaip patiriamas skausmas, įtampa ar diskomfortas rašymo metu. Overvelde ir kt. teigia, kad rašymo sunkumų paplitimas tarp 6 - 12 metų amžiaus vaikų yra nuo 15 iki 33 proc. [16]. R. Giedrienè ir I. Narutavičiūtè teigia, kad iš visų mokymosi sutrikimų labiausiai paplitę yra rašymo, skaitymo ir matematikos mokymosi sutrikimai; jų turejjo 221 mokinys (55 proc.); iš jų net 88 vaikai (40 proc.) turèjo vyraujanti rašymo sutrikimą [8]. Volman ir kt. ištyrè 29 vaikus, turin- čius rašymo problemų, ir 20 vaikų be rašymo problemų, norèdami patikrinti, ar du skirtingi mechanizmai turi ittakos rašymo kokybei: smulkiosios motorikos, koordinacija ir vizualinè - motorinè integracija. Tyrimo duomenimis, veiklos komponentų ịvertinimas darželyje turètų būti orientuojamas i šiuos du pagrindinius veiklos komponentus [17]. K. A. Shire ir kt. smulkiają motoriką taip pat apibūdina kaip pagrindini komponentą mokantis rašymo ankstyvoje stadijoje [23]. Smulkiosios motorikos ịūdžiai, rankų miklumas yra esminiai, norint gebèti manipuliuoti ir kontroliuoti rašymo įrankị. Po keturių savaičių tyrimo rankų miklumas pagerèjo iprasto poveikio ir tiriamojoje (diferenciniu mokymu grịstoje) grupèse, bet sudètų kaištukų skaičius per nustatytą laiką buvo didesnis tiriamojoje grupeje. Iprasto poveikio grupès vaikai, kuriems rankų miklumas buvo lavinamas tik priešmokyklinio ugdymo aplinkoje, statistiškai reikšmingai didesni kaištukų skaičių sudejjo abiem rankomis. Manome, kad tokie tyrimo rezultatai susiję su tuo, kad ịprasto poveikio grupès vaikai kartojo tas pačias rašymo užduotis, tuo pačiu būdu daug kartų, tiriamieji buvo proaktyvūs, t. y. vykdẻ auklètojų nurodytas užduotis, kurių metu centrinè nervų sistema veikè be valios pastangų (automatizmas), tuomet nebuvo sudarytos sąlygos vis iš naujo aktyvuoti skirtingas smegenų zonas [4, 6, 10, 24, 28]. J. H. Carr and R. B. Shepherd teigè, kad didelis smegenų aktyvumas lieka per pirmus tris užduoties pakartojimus, nes véliau vykdomoji sistema smegenyse ijungia automatizmą [4].

Vaikams, kuriems buvo taikomi užsièmimai, grịsti diferenciniu mokymu, rankų miklumas statistiškai reikšmingai pagerejo atliekant užduotis dominuojančia, nedominuojančia, abiem rankomis ir statant bokštelius. Gautus rezultatus galima paaiškinti: užsièmimuose, grịstuose diferenciniu mokymu, svyravimai yra vertinami kaip esminiai judesio sistemoje ir būtini adaptacijai. Svyravimai suprantami kaip įrodymas nestabilioms sistemos sritims, ir sistema, užuot pabandžiusi eliminuoti tai, išnaudoja šiuos svyravimus atrasti galimus atlikimo sprendimus, kurie paruošia asmenis ateities ivykiams. Jeigu detaliai analizuotume judesí, kiekvienas pakartojimas skiriasi nuo ankstesnio judesio, netgi po didelio skaičiaus pakartojimų. Tokios judesių variacijos suaugusiujų dažnai suprantamos kaip destruktyvus triukšmas ar nesugebèjimas pakartoti to pačio judesio, o ne kaip sąlyga, būtina mokymuisi [22]. Vaikai ergoterapeuto pateiktas užduotis atlieka diferenciniu metodu, todèl išplečia savo užduoties atlikimo ribas. Toks motorinių ịgūdžių treniravimo būdas padeda atrasti individualius ir optimalius atlikimo būdus.

Remiantis mūsų žiniomis, šį tyrimą sunku palyginti su kitais tyrimais, nes nèra kitų tyrimų, kurie paaiškintų diferenciniu mokymu grịstos ergoterapijos poveikị priešmokyklinio amžiaus vaikų rašymo ịḡdžiams (rankų miklumui). 
Diferencinio mokymo teorija atsirado stebint esminius adaptyvių sistemų svyravimus. Šiuos svyravimus ir jų įtaką galima stebėti vaikų ankstyvo motorinio vystymosi metu. Vaikai šiuo periodu mokosi daug greičiau nei per visą likusi gyvenimą, todèl galima pabrèžti pirmujų dvejų - penkerių metų mokymosi svarbumą. Šią pagrindinę svyravimų itaką galima stebeti ankstyvoje vaikų motorikos vystymosi stadijoje. Šiuo laikotarpiu vaikai mokosi greičiau nei per visą gyvenimą, tai ịrodo pirmujų dvejų - penkerių augimo metų svarbą mokymuisi. Fundamentalios mokymosi savybès šiuo amžiumi apibūdinamos kaip didelès įvairovès judesiai, mažai pakartojimų ir nedidelis noras klausytis instrukcijų. Jeigu detaliai analizuotume judesi, kiekvienas pakartojimas skiriasi nuo ankstesniojo, netgi po didelio skaičiaus pakartojimų. Tokios judesių variacijos suaugusiujjų dažnai suprantamos kaip destruktyvus triukšmas ar nesugebejjimas pakartoti to pačio judesio, o ne kaip sąlyga, būtina mokymuisi [22].

W. I. Schöllhorn siūlo diferencinị mokymą kaip mokymosi teoriją, priešingą judesių pasikartojimui. Autorius teigia, kad diferencinio mokymo metodas buvo sukurtas pagal individualumo, judejimo sistemos kintamumo ir judesių nekartotinumo principus, kurie remiasi neurofiziologija ir sistemų dinamika. Svyravimai (fluktuacijos) diferenciniame mokyme yra laikomi būdingais judejjimo sistemai ir būtinais adaptacijai. Svyravimai suprantami kaip nestabilių sistemos regionu irodymas ir bandymas ne eliminuoti juos, bet išnaudoti funkcionalumui tobulinti atrandant galimus efektyvius atlikimo būdus, kurie galètų paruošti atletus ir pacientus būsimiems ịvykiams $[21,22]$.

Socialiai aktyvios asmenybès pamatas vaikui vystantis yra rašymo ịūdžių ịgijimas. Tradiciškai nuo pat pradžių vaikai mokomi, kaip taisyklingai formuoti raides (tam tikra brūkšnelių seka). Vèliau eina instrukcijos, kaip pasirinkti rašiklị, kaip jị laikyti, kokie turètų būti rankos judesiai ar kūno poza. Diferencinio mokymo šalininkai siūlo pakeisti tradicini mokymą, paremtą judesių kartojimu, ị atsitiktinius trikdžius ir skirtingus judesių mokymosi modelius kaip efektyvaus mokymosi pagrindą. W. I. Schöllhorn ir kt. atliko 5 savaites trukusi tyrimą ir nustate, kad vaikams, kuriems buvo taikytas diferencinis mokymas, pagerẻjo rašiklio suspaudimas, rašymo greitis ir rašymo sklandumas. Po gausių teigiamų rezultatų taikant diferencinį mokymą sporte bei šio tyrimo teigiamų rezultatų, galima sẻkmingai perkelti diferencini metodą lavinant smulkiają motoriką [27].

Reikètų pabrèžti, kad nėra nustatyto efektyviausio būdo smulkiosios motorikos lavinimui. Ergoterapijos teorija nurodo, kad visas žmogaus gyvenimas yra socialinis vyksmas, o produktyviam vyksmui reikalinga prasminga veikla [11]. Atliekamai veiklai svarbus optimalus judesys. Norint optimizuoti judesio atlikimą, svarbu keisti aplinką, užduotis, funkcinį užduočių lygmenį, taip centrinei nervų sistemai suteikiama proga pačiai atrasti optimalu judesio atlikimo būdą pakitusiomis sąlygomis [25, 20].

Mūsų tyrimas yra pirmasis, vertinantis diferencinio mokymo poveiki priešmokyklinio amžiaus vaikų rankų miklumui. Tyrimas parodè, kad i ịprastą priešmokyklinio ugdymo programą įtraukus diferencinį mokymą, rankų miklumas, vertinant „Kaištukų lentos testu“, reikšmingai pagerèjo visose keturiose užduotyse, kai tuo tarpu vaikams, kurie buvo lavinami vien pagal priešmokyklinę ugdymo programą, rankų miklumas reikšmingai pagerėjo užduotị atliekant abiem rankomis.

\section{Išvada}

Priešmokyklinio amžiaus vaikų rankų miklumas buvo geresnis taikant ịprastą ugdymo programą ir diferencinị mokymą nei taikant vien ịprastą priešmokyklinio ugdymo programą.

\section{Literatūra}

1. Birontienė Z. Priešmokyklinio amžiaus vaikų smulkiosios motorikos ugdymas. Klaipeda, 2008.

2. Birontienė Z. Ugdymo įtaka priešmokyklinio amžiaus vaikų rankų koordinacijos rezultatų kaitai. Sporto mokslas, 2010; 1(59):62-69.

3. Bruni M. Fine motor skills in children with Down syndrome. A Guide for parents and professionals. In Model of hand skill development. Jungtinès Amerikos Valstijos. Woodbine House, 2016; 1-6.

4. Carr JH, Shepherd RB. Stroke rehabilitation. Guidelines for exercise and training to optimize motor skill, 2008.

5. Clough TN, Malone JC, Robertson ChM. Developing a comprehensive handwriting curriculum utilizing the handwriting without tears ${ }^{\mathrm{TM}}$ approach for typically developing elementary school aged children [magistro baigiamasis darbas]. [Kalifornija]: Dominican University of California, 2013; 76.

6. Davids K, Bennet $\mathrm{S}$, Newell K. Movement system variability. Champaign, IL: Human Kinetic; 2006. EWOMS'09. European Workshop on Movement Science, Lisbon, Portugal, 2009; 45.

7. Frank TD, Michelbrink M, Beckmann H, Schöllhorn WI. A quantitative dynamical systems approach to differential learning: self-organization principle and order parameter equations. Biol Cybern 2008;98(1):19-31.

$$
\text { https://doi.org/10.1007/s00422-007-0193-x }
$$

8. Giedrienè R., Narutavičiūtè I. Mokymosi sutrikimai ir vaiko socializacija. Socialinis ugdymas /Sumanioji edukacija, 2015;41(2):87-98.

https://doi.org/10.15823/su.2015.46

9. Ginieri-Coccois M, Rotsika, Skevington S, Papaevangelou S, Malliori M, Tomaras, V, Kokkevi A. Quality of life in new diagnosed children with specific learning disabilities (SpLD) 
and differences from typically developing children: study of child and parent report. Child: Care, Health and Development 2012;39(4):581-591.

https://doi.org/10.1111/j.1365-2214.2012.01369.x

10. Herzfeld DJ, Shadmehr R. Motor variability is not noise, but grist for the learning mill. Nature Neuroscience 2014;17(2):149-50.

https://doi.org/10.1038/nn.3633

11. Kriščiūnas A., Mingaila S., Petruševičienė D., Rapolienė J., Bikute I. Ergoterapijos paradigma reabilitacijos srityje ir jos profesinis reglamentavimas. Reabilitacijos mokslai: slauga, kineziterapija, ergoterapija, 2009;1(1):10-14.

12. Kushki A, Chau T, Anagnostou E. Handwriting difficulties in children with autism spectrum disorders: a scoping review. Journal of Autism and Developmental Disorder 2011; 21(12):1706-1716.

https://doi.org/10.1007/s10803-011-1206-0

13. Malinauskienė D. Priešmokyklinio ugdymo pakopos svarba vaikų socialinès kompetencijos ugdymui. Socialinis darbas, 2006; 5(1):116-122.

14. Mažeikaitė V. Ergoterapija lavinant pradinių klasių moksleivių rašymo igūdžius [magistro baigiamasis darbas]. [Kaunas]: Lietuvos sveikatos mokslų universitetas, Medicinos akademija, 2012; 120.

15. Naujalienė A. Ikimokyklinio amžiaus mergaičių, kurioms kūdikystejje buvo nustatyti motorinès raidos sutrikimai, stambiosios ir smulkiosios motorikos iqvertinimas [magistro baigiamasis darbas]. [Kaunas]: Lietuvos sveikatos mokslų universitetas, Medicinos akademija, 2012; 71.

16. Overvelde A, Hulstijn W. Handwriting development in grade 2 and grade 3 primary school children with normal, at risk, or dysgraphic characteristics. Research in Developmental Disabilities 2011:32(2);540-548.

https://doi.org/10.1016/j.ridd.2010.12.027

17. Piek J, Hands B, Licari M. Assessment of motor functioning in the preschool period. Neuropsychology Review 2012; 22 (4):402-413.

https://doi.org/10.1007/s11065-012-9211-4

18. Puranik SC, Loningan JL, Kim YS. Contributions of emergent literacy skills to name writing, letter writing, and spelling in preschool children. Early Childhood Research Quarterly 2011:26(4); 465-474.

https://doi.org/10.1016/j.ecresq.2011.03.002

19. Radžiūnienė M. Motorikos pokyčiai kūdikystèje ir vaikystėje, taikant pagal amžių adaptuotą judesių mokymą[daktaro disertacija]. [Kaunas]: Lietuvos sveikatos mokslų universitetas, Medicinos akademija, 2016; 142.

20. Repšaite V. Diferencinio mokymo poveikis asmenų, patyrusių galvos smegenų insultą, funkciniams judesiams ir savarankiškumui [daktaro disertacija]. Kaunas. Lietuvos sveikatos mokslų universitetas, Medicinos akademija, 2015; 137.

21. Schöllhorn WI, Beckmann H, Davids K. Exploiting system fluctuations. Differential training in physical prevention and rehabilitation programs for health and exercise. Medicina (Kaunas), 2010; 46(6):365-73.

https://doi.org/10.3390/medicina46060052

22. Schöllhorn WI, Beckmann H, Janseen D, Drepper, J. Stochastic perturbation in athletics field events enhance skill acquisition. Motor learning in practice - A constraints-led approach. In: Renshaw I, Davids K, Savelsbergh GJP, editors. London. Routledge, 2010.

23. Shire KA, Hill LJB, Snapp-Childs W, Bingham GP, Kountouriotis GK, Barber S. ir kt. Robot guided 'pen skill' training in children with motor difficulties. PLoS ONE. 2016; 11(3): 1-14. https://doi.org/10.1371/journal.pone.0151354

24. Skurvydas A. Judesių mokslas: raumenys, valdymas, mokymas, reabilitavimas, sveikatinimas, treniravimas, metodologija: vadovèlis. Kaunas. Lietuvos kūno kultūros akademija, 2008.

25. Skurvydas A. Modernioji neuroreabilitacija: judesių valdymas ir proto treniruote. Kaunas. Vitae Litera, 2011.

26. Van Hartingsveldt M. Ready for handwriting? Development of the Writing Readiness Inventory Tool In Context (WRITIC) for kindergarten children in the prewriting phase. In Van Hartingsveldt M. General Introduction. Radboud Universiteit Nijmegen 2014; 18-19.

27. Vehof K, Janssen D, Schöllhorn WI. Handwriting acquisition in primary school by means of the differential learning approach. In D. Ara_ujo, J. Cabri, \& J. Barreiros (Eds.), EWOMS'09. European Workshop on Movement Science, Lisbon, Portugal, $2009 ; 45$.

28. Wu H, Miyamoto Y, Gonzales-Castro LN, Olveczky BP, Smith MA. Temporal structure of motor variability is dynamically regulated and predicts motor learning ability. Nat Neurosci 2014; $17: 312-321$.

https://doi.org/10.1038/nn.3616

\section{THE EFFECT OF DIFFERENTIAL TRAINING ON MANUAL DEXTERITY OF PRESCHOOL CHILDREN P.Zachovajevas, V.Kaktienė, G.Šegždaitė, J.Jurènaitė, K.Berškienè}

Key words: differential training, manual dexterity, fine motor, preschool education, writing skills, preschool children.

Summary

Lifelong learning begins with one of the most important stages of education - preschool education, therefore, children need fine motor skills such as strength and suppleness required to take the writing tool in order to carry out the necessary manipulative actions needed for writing $[2,15]$. Differential training is based on the principle of non repetition of the movement. It is based on the fact that the subject himself finds his own optimal performance models for learning complex motor skills [19].

Subjects and methods of research. The research was carried out at Kaunas institution of preschool education. The selection criteria were met by 27 children of preschool age, 15 girls and 12 boys. During the study, an initial and repeated assessment of ma- 
nual dexterity of the preschool children was carried out. All preschool children were divided into study and conventional impact groups. Study group consisted of 14 children. They had differential training (twice a week) combined with a preschool curriculum (three times a week) applied. The conventional impact group consisted of 13 children who followed the usual preschool curriculum five times a week. The research lasted for 4 weeks. Children's manual dexterity was measured by the „Purdue pegboard test” before the classes and after four weeks of training.

Results. Children who were trained following the preschool curriculum, combined with the differential training, put significantly more $(\mathrm{p}<0,05)$ pegs with dominant and non dominant hands and constructed towers than the children who had only the usual preschool curriculum applied. By comparing the results of the children putting the pegs with both hands in conventional impact and study groups we found a higher change $(p<0,05)$ in the study group. The children of the study group who, besides the usual curriculum had differential teaching applied, have put more pairs of pegs than children who have just been doing the tasks of conventional teaching.

Conclusion. The manual dexterity of preschool children was better when applying usual curriculum combined with a differential teaching rather than applying standard preschool curriculum alone.

Correspondence to: viktorija.kaktienè@gmail.com

Gauta 2018-10-16

\section{KVIEČIAME PRENUMERUOTI "SVEIKATOS MOKSLŲ" ŽURNALĄ 2019 METAIS!}

Žurnalas "Sveikatos mokslai" (Index Copernicus, EBSCO host (Academic Search Complete), Gale (Academic OneFile), ProQuest (Ulrich's, Summon), Australia (ERA) 2012 Journal List (ERA ID 34962) skirtas visų specialybių gydytojams, slaugytojams ir kitiems specialistams, spausdina mokslinius straipsnius lietuvių, anglų kalbomis. Reikalavimai straipsniams atitinka mokslo leidiniams keliamus reikalavimus. Žurnalas kioskuose neparduodamas. Žurnalą, kuris leidžiamas kartą per du mènesius, galima užsiprenumeruoti visuose Lietuvos pašto skyriuose, taip pat internetu: www.prenumeruok.lt

Prenumeratos kaina nesikeičia: visiems metams - 36 EUR, šešiems mẻnesiams - 18 EUR, keturiems mẻnesiams - 12 EUR, dviem mẻnesiams - 6 EUR. Prenumeratos kodas: 5348.

Žurnalo autoriams straipsnių spausdinimas mokamas. 